\title{
CASSAVA AND TURMERIC FLOUR BLENDS AS NEW RAW MATERIALS TO EXTRUDED SNACKS
}

\author{
Misturas de farinhas de mandioca e de açafrão como novas \\ matérias-primas para snacks extrusados
}

Alessandra Mussato Spinello', Magali Leonel², Martha Maria Mischan ${ }^{3}$, Ezequiel Lopes do Carmo ${ }^{4}$

\begin{abstract}
Short cooking time and ability to blend varieties of food ingredients have made extrusion cooking a medium for low-cost and nutritionally improved food products. The effect of moisture, extrusion temperature and amount of turmeric flour mixed with cassava flour on physical characteristic of puffed snacks was evaluated in this work. Extrusion process was carried out using a singlescrew extruder in a factorial central composite design with four factors. Results showed effect of extrusion parameters on dependents variables. High expansion, low browning, low water solubility index, intermediate water absorption index and high crispness desirable characteristics to puffed snacks are obtained in conditions of $12 \%$ moisture, $5 \%$ turmeric flour, $105^{\circ} \mathrm{C}$ of temperature and $250 \mathrm{rpm}$ of screw speed. These paper point to the potential still unexplored of the use of flours of cassava and turmeric as raw materials in the development of extruded puffed snacks.
\end{abstract}

Index terms: Curcuma longa, Manihot esculenta, extrusion.

\section{RESUMO}

O curto tempo de cozimento e capacidade para misturar vários ingredientes fizeram da extrusão um meio para o desenvolvimento de produtos alimentares de baixo custo e nutricionalmente melhorados. Neste trabalho foram avaliados os efeitos da umidade, da temperatura de extrusão e da quantidade de farinha de açafrão misturada com a farinha de mandioca nas características físicas de snacks expandidos. O processo de extrusão foi realizado em um extrusor monorrosca, utilizando o delineamento central composto rotacional com quatro fatores. Os resultados mostraram efeito dos parâmetros de extrusão sobre as variáveis dependentes. Alta expansão, baixo escurecimento, baixo índice de solubilidade em água, índice de absorção de água médio e elevada crocância, características desejáveis para snacks extrusados, podem ser obtidas em condições de $12 \%$ de umidade, $5 \%$ de farinha de açafrão, $105^{\circ} \mathrm{C}$ de temperatura e $250 \mathrm{rpm}$ de rotação do parafuso. Esses resultados apontam para o potencial ainda pouco explorado do uso de farinhas de mandioca e açafrão como matéria-prima para o desenvolvimento de snacks.

Termos para indexação: Curcuma longa, Manihot esculenta, extrusão.

\section{INTRODUCTION}

Extrusion cooking is an important processing technique in the food industry. This processing can efficiently create novel products that might not be possible through other processing methods (Cisneros; Kokini, 2002).

Extruded foods have been proven to provide nutritious products and combine quality ingredients and nutrients to produce processed foods that contain precise levels of each required nutrient (Yagci; Gögüs, 2008).

Food extruders provide thermo-mechanical and mechanical energy (shear) necessary to cause physicochemical changes of raw materials with an intense mixing for dispersion and homogenization of ingredients (Anton; Luciano, 2007).
Extruded foods are composed mainly of cereals, starches, and/ or vegetable proteins. The major role of these ingredients is to give structure, texture, mouth feel, bulk, and many other characteristics desired for specific finished products (Anton; Fulcher; Arntfield, 2009).

Extrusion parameters (temperature, screw rotation, throughput rate, die diameter, etc.) and raw-material characteristics (moisture, particle size distribution, content of protein, fiber, lipids, etc.) have great influence on hardness, expansion, color and internal structure of expanded snacks, with direct consequences on their acceptance (Ding et al.,2005).

Cassava (Manihot esculenta Crantz) is one of the most economically important crops in Brazil, Thailand and other tropical countries. It is an abundant and

1Universidade Estadual Paulista “Júlio de Mesquita Filho"/UNESP - Centro de Raízes e Amidos Tropicais/CERAT - Rua José Barbosa de Barros - Cx. P. 1780 18610-307 - Botucatu - SP - Brasil - alespinello02@hotmail.com

¿Universidade Estadual Paulista “Júlio de Mesquita Filho"/UNESP - Centro de Raízes e Amidos Tropicais/CERAT - Botucatu - SP - Brasil

3Universidade Estadual Paulista "Júlio de Mesquita Filho"/UNESP - Departamento Bioestatística - Botucatu - SP - Brasil

${ }^{4}$ Universidade Estadual Paulista "Júlio de Mesquita Filho"/UNESP - Faculdade de Ciências Agrominerais/FCA - Botucatu - SP - Brasil

Received in september 2,2013 and approved in november 4, 2013

Ciênc. Agrotec., Lavras, v.38, n. 1, p.68-75, jan./fev., 2014 
cheap agricultural source of starch and flour production (Suppakul et al., 2013).

Brazil is the third largest producer of cassava. Cassava is grown in all states of country, taking outstanding importance in food and feed, and is used as raw material in numerous industrial products (Leonel, Freitas; Mischan, 2009).

Turmeric (Curcuma longa L.), originated from India and found in South American countries, is an important economic crop cultivated for its underground rhizomes which are widely used in drugs, cosmetic industries, condiments, curry stuffs and in religious and auspicious occasions. It has been traditionally used in indigenous herbal medicines due to its biological activities. Due to its easy digestibility, turmeric has been used in industry to prepare special food and children's foods. Turmeric has long been known in India and many other countries as an important dietary source in addition to their use in traditional medicine for wound healing to cure inflammation and stomach acidity (Jyothi, Moorthy; Vimala, 2003; Kumar et al., 2006; Panneerselvam et al., 2007).

The extrusion process adding value to cassava and turmeric flours because allows their use as ingredients in food industries. These flours are products of low cost of production and with wide acceptance by ethnic, social and economic aspects.

The production of puffed snacks foods of cassava and turmeric flour blends through extrusion could be launched into the market on the basis of adding some utilities such as variety and novelty, which are important to modern consumers.

Considering that desirable properties in the extrudates are obtained by finding the appropriate processing condition as well as the proper composition of the raw material, this study aimed to evaluate the effect of extrusion conditions and raw material composition on physical properties of extruded snacks obtained from mixtures of cassava and turmeric flours.

\section{MATERIALS AND METHODS}

The employed raw materials were: industrial cassava flour (Plaza Alimentos, Santa Maria da Serra, São Paulo state, Brazil) and turmeric flour.

For the production of turmeric flour the rhizomes harvested after 12 months after planting were washed with water. The rhizomes were sliced and drying in oven with air circulation at the temperature of $55^{\circ} \mathrm{C}$ for 24 hours. After drying the material was ground using mill knives to obtain the flour (MA680 - Marconi, Brazil).

Proximate analysis (moisture, protein, fat, ash and crude fiber) was carried out on cassava and turmeric flours, determined according to the methods described in AOAC (2000). Total carbohydrates were calculated by differences.

Cassava and turmeric flour mixtures were prepared and after homogenization in a homogenizer in "Y" TE201/5 (Tecnal, Brazil) by 5 minutes, 28 samples of $1 \mathrm{~kg}$ were separated for moisture conditioning.

Extrusion was carried out using a complete line of INBRA RX50 (Inbramaq, Brazil), which has a motor coupled with a speed reducer (extrusion by mechanical friction), besides a single extrusion screw, with $130 \mathrm{~mm}$ of barrel diameter, $440 \mathrm{~mm}$ of extruder length, a hydraulic cooling system for temperature control, variable speed, and $50 \mathrm{~kg} \mathrm{~h}^{-1}$ capacity.

The extrusion constant parameters were: extrusion temperature in the $1^{\text {st }}\left(20\right.$ to $\left.25^{\circ} \mathrm{C}\right)$ and $2^{\text {nd }}$ zones (40 to $\left.45^{\circ} \mathrm{C}\right)$; screw compression ratio (3:1); screw diameter $(19 \mathrm{~mm})$, die diameter $(4 \mathrm{~mm})$; feed rate $\left(150 \mathrm{~g} \mathrm{~min}^{-1}\right)$; and cutting speed $(90 \mathrm{rpm})$.

The variable parameters of process were: turmeric flour amount, feed moisture; barrel temperature in the $3^{\text {rd }}$ zone; and screw speed (Table 1). The variation ranges between the upper and the lower limit of variables were established based on preliminary tests.

During the extrusion process a portion of the next test material was used to purge the extruder. It was collected $600 \mathrm{~g}$ of extruded sample after achieving steady-

Table 1 - Levels of variation and variable parameters of the extrusion process.

\begin{tabular}{lccccc}
\hline \multirow{2}{*}{ Independent variables } & \multicolumn{5}{c}{ Levels of variation } \\
\cline { 2 - 6 } & $-<$ alpha $>$ & -1 & 0 & +1 & $+<$ alpha $>$ \\
\hline Turmeric flour (\% wet basis) & 2 & 4 & 6 & 8 & 10 \\
Screw speed (rpm) & 230 & 240 & 250 & 260 & 270 \\
Extrusion temperature $\left({ }^{\circ} \mathrm{C}\right)$ & 80 & 90 & 100 & 110 & 120 \\
Moisture content $(\%)$ & 12 & 14 & 16 & 18 & 20 \\
\hline
\end{tabular}

$<$ alpha $>=2$ 
state flow in the extruder. The extruded samples were dried $\left(40^{\circ} \mathrm{C}\right)$ to the desired moisture $(6-7 \%)$ in oven with air circulation (MA037 - Marconi, Brazil). Each dried samples was divided in two portions and kept in plastics bags hermetically sealed until their evaluation.

The expansion index (EI) of snacks was evaluated after extrusion and before drying. It was determined using a digital caliper. Expansion indexes are derived from the division of radial expansion by the die orifice diameter (4.0 $\mathrm{mm}$ ). The considered value was obtained by the arithmetic mean of measurements of 20 different expanded products in each treatment.

Specific volume (SV) of snacks was determined according to the mass displacement method (millet seed) using a graduated cylinder.

Water absorption index (WAI) and water solubility index (WSI) were assessed before and after extrusion process (Anderson et al. 1969). The water absorption index (WAI) is the weight of gel obtained per gram of dry ground sample. The extrudates were ground to a mean particle size of approximately $150 \mu \mathrm{m}$. A $2.5 \mathrm{~g}$ sample was dispersed in $25 \mathrm{~g}$ of distilled water using a glass rod to break up any lumps. After stirring for $30 \mathrm{~min}$, the dispersions were rinsed into tarred centrifuge tubes, made up to $32.5 \mathrm{~g}$, and centrifuged at $5000 \mathrm{rpm}$ for 10 $\mathrm{min}$. The water absorption index (WAI) is the weight of gel obtained per gram of dry ground sample. The water solubility index (WSI) is the percentage of dry matter recovered after the supernatant is evaporated from the water absorption determination.

Color measurements (CIE L*, a*, b* color space), assessed before and after extrusion process, were performed on ground samples using a Minolta CR-400 model colorimeter (Konica Minolta, Ramsey, NJ, USA). The color of extrudates was expressed as the average of three $\mathrm{L}^{*}, \mathrm{a}^{*}$, and $\mathrm{b}^{*}$ readings, where $\mathrm{L}^{*}$ stands for brightness, $+a^{*}$ redness, $-a^{*}$ greenness, $+b^{*}$ yellowness, and $-b^{*}$ blueness. A white calibration plate was used to standardize the equipment prior to color measurements.

The hardness of samples was determined using a texture analyzer TA-XT2 (Stable Micro Systems, Surrey, England) with a $50 \mathrm{~kg}$ load cell and a probe HDP/WBV (Warner Bratzler set with "V" slot blade for USDA Standart). The test speed was $1 \mathrm{~mm} / \mathrm{s}$. Ten extrudates were assayed for each treatment.

Response Surface Methodology describes the behavior of a system in which the independent variables $\left(\mathrm{X}_{\mathrm{k}}\right)$ and the dependent variable or response $\left(\mathrm{Y}_{\mathrm{i}}\right)$ are combined. The response is a function of the levels at which those factors were combined and defined. Within the proposed variation ranges, i.e. within the region characterized by these levels, the behavior of each response can be predicted in a general form according to the equation:

$\mathrm{Y}_{1}=\beta_{\mathrm{o}}+\beta_{1} \mathrm{X}_{1}+\beta_{2} \mathrm{X}_{2}+\beta_{3} \mathrm{X}_{3}+\beta_{4} \mathrm{X}_{4}+\beta_{11} \mathrm{X}_{1}{ }^{2}+\beta_{22} \mathrm{X}_{2}{ }^{2}+$ $\beta_{33} X_{3}^{2}+\beta_{44} X_{4}^{2}+\beta_{12} X_{1} X_{2}+\beta_{13} X_{1} X_{3}+\beta_{14} X_{1} X_{4}+\beta_{23} X_{2} X_{3}+$ $\beta_{24} X_{2} X_{4}+\beta_{34} X_{3} X_{4}+\varepsilon$

Where:

$\mathrm{Y}_{1}=$ Dependent variable or response function;

$\mathrm{X}_{1}, \mathrm{X}_{2}, \mathrm{X}_{3}, \mathrm{X}_{4}=$ Values of the independent variables;

$\beta_{\mathrm{o}}=$ Coefficient relative to the line interception with the response axis;

$\beta_{1}, \beta_{2}, \beta_{3}, \beta_{4}=$ Linear coefficients assessed through least square method;

$\beta_{11}, \beta_{22}, \beta_{33}, \beta_{44}=$ Coefficients of quadratic variables;

$\beta_{12}, \beta_{13}, \beta_{14}, \beta_{23}, \beta_{24}, \beta_{34}=$ Coefficients of interaction between independent variables;

$\varepsilon=$ Experimental error.

The model was fitted by the option "step-wise" of SAS program; the obtained model was validated through F-test using the pure error mean square as denominator. The response surfaces plots were drawn from the adjusted models using the software Statistica ${ }^{\circledR}$ 6.0.

The snacks were sensorial evaluated through an acceptance test, using a 9-point hedonic scale where the value 1 corresponded to "disliked very much" and 9 to "liked very much". In the sensorial analysis 100 people tasted the snacks in relation to global acceptance. Before the evaluation snacks were coated with solution of salt $(3 \%)$ and oil (20\%). The evaluators were students of the São Paulo State University (UNESP, Brazil), men and women, between 18 and 25 years old.

\section{RESULTS AND DISCUSSION}

The results obtained in the characterization of turmeric flour showed high total carbohydrate content $(62.71 \%)$ and considerable amounts of other components such as fibers $(9.64 \%)$, lipids $(5.69 \%)$, protein $(3.22 \%)$ and ash $(4.34 \%)$ in dry basis, which values this flour as an ingredient in the development of new extruded products.

The composition of cassava flour showed $82.52 \%$ of total carbohydrate. Moisture (12.3\%) and ash contents $(0.54 \%)$ of flour are in agreement with the limit established by Brazilian legislation (maximum of $13.0 \%$ and $2.0 \%$ respectively) (Brazil, 2011). Moreover, cassava flour showed a low content of lipids $(0.32 \%)$ and proteins $(1.43 \%)$ and moderate fiber content $(2.89 \%)$. 
Color analysis of the flours before the extrusion process showed that turmeric flour has a high presence of the chrome $b$ positive (yellow) (47.76) and chrome a positive (red) (13.07) and low luminosity (53.41). The cassava flour showed high brightness (81.63) and presence of $\mathrm{a}^{*}$ and $\mathrm{b}^{*}$ positives ( 1.36 and 17.68 , respectively) but with less intense than the turmeric flour.

Analysis of water solubility index (WSI) and water absorption index (WAI) of the flours before the extrusion process showed higher values of these indexes for the turmeric flour $\left(21.42 \%\right.$ WSI and $7.69 \mathrm{~g}$ gel. $\left.^{-1} \mathrm{WAI}\right)$ than observed in cassava flour $\left(4.48 \%\right.$ WSI and $6.31 \mathrm{~g} \mathrm{gel.g}^{-1}$ WAI), probably due no starchy components of turmeric flour. Low water absorption index and water solubility index in cassava flour before extrusion process were also found in other study (Lustosa et al., 2009).

Several reports had attempted to relate extrusion parameters to chemical and physical properties of extrudates such as raw material composition, feed moisture, screw speed, extrusion temperature and feed rate (Hagenimana, Ding; Fang, 2006; Yuliani et al., 2006).

Table 2 summarizes the estimated regression coefficients for the models fitted to the experimental results and their significance as well as their corresponding coefficients of determination.

The expansion occurring in a food material depends on the pressure differential between the die and atmosphere. The high pressure close to the discharge of the matrix is reduced when the products leaves the extruder, causing flash evaporation of water and expansion of the product.

As the conditions used in the processing of cassava and turmeric flour mixtures the expansion index ranged from 3.04 to 4.33. Data analysis showed negative linear effect of moisture on expansion index (Table 2). The model

Table 2 - Regression equation coefficients.

\begin{tabular}{|c|c|c|c|c|c|c|c|c|}
\hline \multirow{2}{*}{ Parameters } & \multicolumn{8}{|c|}{ Response variables } \\
\hline & EI & SV & WAI & WSI & $L^{*}$ & $a^{*}$ & $b^{*}$ & $\mathrm{H}$ \\
\hline$\beta_{\mathrm{o}}$ & 1.27 & 3.80 & 7.24 & 8.41 & 63.25 & 6.71 & 60.23 & 2.64 \\
\hline$\beta_{1}$ & -0.08 & -0.23 & $-0.64 * * *$ & $-3.03 * * *$ & $-2.91 * * *$ & $1.93 * * *$ & $-2.43 * * *$ & 0.09 \\
\hline$\beta_{2}$ & -0.12 & -0.37 & $-0.51 * * *$ & $-2.01 *$ & -0.82 & $0.36^{* * *}$ & $-1.29^{*}$ & $0.54 * * *$ \\
\hline$\beta_{3}$ & -0.44 & $-1.32 * * *$ & $-0.65 * * *$ & $-3.48 * * *$ & $-1.71 * * *$ & $0.61 * * *$ & $-1.48^{*}$ & $-0.54 * * *$ \\
\hline$\beta_{4}$ & $0.09 * *$ & 0.27 & -0.09 & -1.17 & 0.55 & -0.08 & 0.93 & -0.04 \\
\hline$\beta_{11}$ & 0.02 & 0.05 & $0.04 *$ & $1.80 *$ & 0.52 & $-0.26 * * *$ & 0.08 & 0.05 \\
\hline$\beta_{22}$ & 0.10 & 0.31 & $0.27 * *$ & $2.07 * *$ & -0.05 & 0.05 & 0.26 & -0.07 \\
\hline$\beta_{33}$ & 0.03 & 0.08 & $0.32 * * *$ & $2.83 * * *$ & -0.05 & 0.01 & $-0.41 *$ & 0.05 \\
\hline$\beta_{44}$ & 0.04 & 0.12 & 0.48 & $2.24 * *$ & 0.69 & 0.08 & 1.18 & $-0.22 *$ \\
\hline$\beta_{12}$ & 0.10 & 0.31 & -0.07 & 0.41 & -0.18 & -0.12 & $-0.48 *$ & -0.01 \\
\hline$\beta_{13}$ & -0.04 & -0.12 & -0.04 & 0.20 & -0.79 & 0.01 & -1.86 & $0.42 * *$ \\
\hline$\beta_{14}$ & 0.07 & 0.20 & 0.14 & 0.78 & 0.50 & -0.13 & 0.52 & -0.13 \\
\hline$\beta_{23}$ & 0.05 & 0.14 & 0.01 & 0.79 & -0.60 & 0.15 & -1.13 & -0.04 \\
\hline$\beta_{24}$ & 0.01 & 0.04 & 0.11 & 0.36 & -0.25 & 0.08 & 0.07 & 0.16 \\
\hline$\beta_{34}$ & 0.08 & 0.23 & 0.01 & -0.26 & 0.09 & -0.01 & 0.29 & 0.16 \\
\hline $\mathrm{R}^{2}$ & 0.5605 & 0.5602 & 0.8301 & 0.8031 & 0.8498 & 0.9749 & 0.6830 & 0.7693 \\
\hline$F$ value & 1.37 & 1.36 & 5.23 & 4.37 & 6.06 & 41.68 & 2.31 & 3.57 \\
\hline C.V. & 39.74 & 39.79 & 8.64 & 26.86 & 3.11 & 6.41 & 5.67 & 25.43 \\
\hline $\operatorname{Pr}>F$ & 0.2778 & 0.2783 & 0.0015 & 0.0037 & 0.0007 & $<0.0001$ & 0.0598 & 0.0099 \\
\hline
\end{tabular}

$\beta_{1}=$ percentage of turmeric flour, $\beta_{2}=$ extrusion temperature, $\beta_{3}=$ moisture, $\beta_{4}=$ screw speed, EI= expansion index, $\mathrm{SV}=$ specific volume, $\mathrm{WAI}=$ water absorption index, $\mathrm{WSI}=$ water solubility index, $\mathrm{L}^{*}=$ luminosity, $\mathrm{a}^{*}=$ chroma $\mathrm{a}^{*}, \mathrm{~b}^{*}=$ chroma $\mathrm{b}^{*}, \mathrm{H}=$ hardness; $\mathrm{R}^{2}=$ determination coefficient; $* * *=\mathrm{p}<0,001 ; * *=\mathrm{p}<0,01 ; *=\mathrm{p}<0,05$. 
proposed was not significant $(\mathrm{p}>0.05)$ and it was not a predictor model (lack of fit $<0.05$ ).

The expansion of starchy materials is inversely proportional to the moisture of raw material. Increased moisture can change the molecular structure of amylopectin reducing the elastic viscosity and thus decreasing the expansion (Ding et al., 2005).

Specific volume is a main performance index for extrusion puffed food. It is a measure of volumetric expansion, which is the sum of radial and axial expansions. The specific volume (SV) of extruded products ranged from $1.08 \mathrm{~mL} \cdot \mathrm{g}^{-1}$ to $8.19 \mathrm{~mL} \cdot \mathrm{g}^{-1}$. Moisture showed negative linear effect on specific volume (Table 2$)$. The fitted model cannot be considerably predictive (Lack of fit $p<0.05$ ).

Foods with lower moisture tend to be more viscous than those with higher moisture and, therefore, the pressure differential would be smaller for higher moisture foods, leading to a less expanded product (Singh, Gamilath; Wakeling, 2007).

Water solubility index (WSI), often used as an indicator of degradation of molecular components, depends on the intensity and type of reactions that occur during extrusion, influencing the amount of soluble molecules. The values obtained for the water solubility index of the extruded products ranged from $8.05 \%$ to $31.93 \%$.

The analysis of the regression coefficients showed linear and squared effects of amount of turmeric flour, temperature and moisture, as well as squared effect of screw speed on water solubility index of extrudates (Table 2 ). The fitted model can be considerably predictive (Lack of fit $p>0.05$ ). Yagci and Gogus (2008) reported that with significant probability values $(p<0.001)$ and nonsignificant lack of fit, the models could be adequately used as predictor models.

When the extrusion parameters are in intermediate conditions tested lower WSI are observed (Figure 1).
An increase in the amount of dextrinized starch during extrusion cooking results in an increase in water solubility index. However, molecular interactions between degraded starch, protein, and lipid components may reduce solubility (Dogan; Karwe, 2003).

The water absorption index (WAI) measures the volume occupied by the starch after swelling in excess water and indicates the integrity of starch in aqueous dispersion. Results showed that WAI of extruded products ranged from $5.72 \mathrm{~g} \mathrm{gel.}^{-1}$ to $10.57 \mathrm{~g} \mathrm{gel.}^{-1}$. Data analysis showed linear effects of amount of turmeric flour, extrusion temperature and moisture, as well as squared effects of these parameters (Table 2). The model can be considerably predictive.

Higher values of WAI can be observed in conditions of low amount of turmeric flour, temperature and moisture, with high screw speed (Figure 2).

Low moisture levels coupled with the high rotational contribute to the breaking and collapsing of the structure of the starch granules promoting the formation of dextrines and decreasing water absorbency. Moreover, higher humidity values decrease the effect of shear on starch granules and in combination with higher temperatures favor the process of gelatinization and consequently the release of groups (-OH).

Increase in the value of WAI may probably be caused by uncovering of hydrophilic groups in extruded starch-protein material, by unfolding and loosening of biopolymer chains, greater availability and easier penetration of structures by water molecules (Marzec; Lewicki, 2006).

The content of lipids in turmeric flour can have influenced the water absorption index of extruded products. It is believed that the lubricant effect of fat inside the extruder first reduces the friction between dough and screw elements as well as between dough and
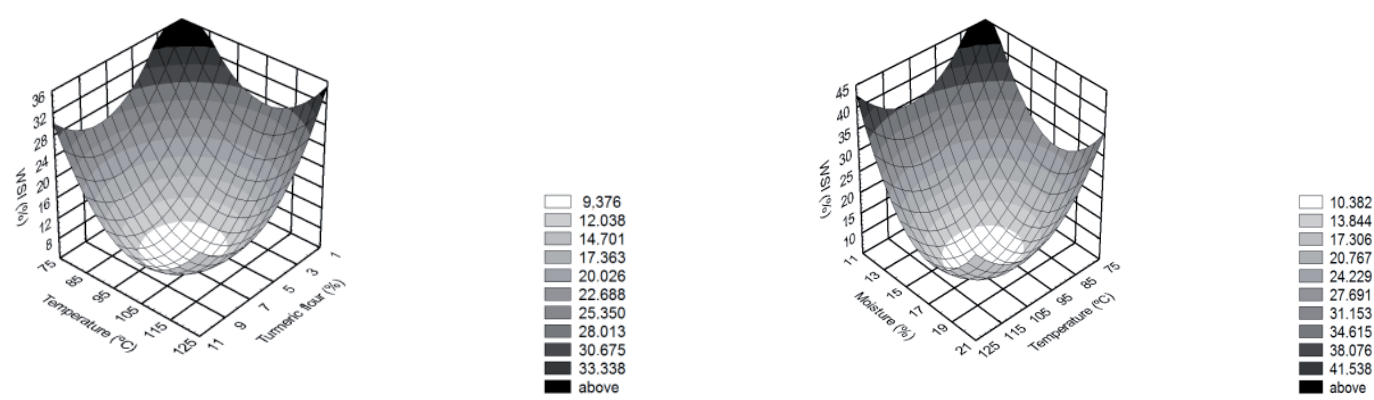

Figure 1 - Effect of temperature, moisture, screw speed and amount of turmeric flour on water solubility index of extruded snacks.

Ciênc. Agrotec., Lavras, v.38, n. 1, p.68-75, jan./fev., 2014 
barrel resulting in the decrease of the dough temperature; and second, prevents the starch granules from severe mechanical breakdown by shear stress (De Pilli et al., 2011).

Color is one of the most important attributes of food products. Measurement of color has been applied for determining the residence time distribution in a food extruder and for studying different aspects of non-enzymatic browning during extrusion cooking (Apruzzese et al., 2003; Valadez-Blanco et al., 2007).

Processing conditions used in extrusion (high temperature and low moisture) are recognized to favor the reaction between reducing sugars and aminoacids, that results in the formation of colored compounds and in the reduction of lysine aminoacid. If browning is too intense, colors and undesirable tastes may come up. Besides, the color changes during the process can be considered as an indicator to evaluate the intensity of the process in terms of chemical and nutritional changes.

Results of color analysis of extruded products showed that the values of the $\mathrm{L}^{*}$ component from extruded products varied from 54.43 to 70.87 . In conditions of high moisture and high amount of turmeric flour luminosity decreases (Table 2, Figure 3).

The results obtained for the $a^{*}$ value of the extruded products ranged from 1.64 to 9.61. Analysis of the regression coefficients showed linear effects of amount of turmeric flour, temperature and moisture, as well as squared effect of amount of turmeric flour on this component of chromaticity (Table 2, Figure 3).

Responses of the $b^{*}$ color parameter varied according to the treatment from 49.27 e 67.39 indicating
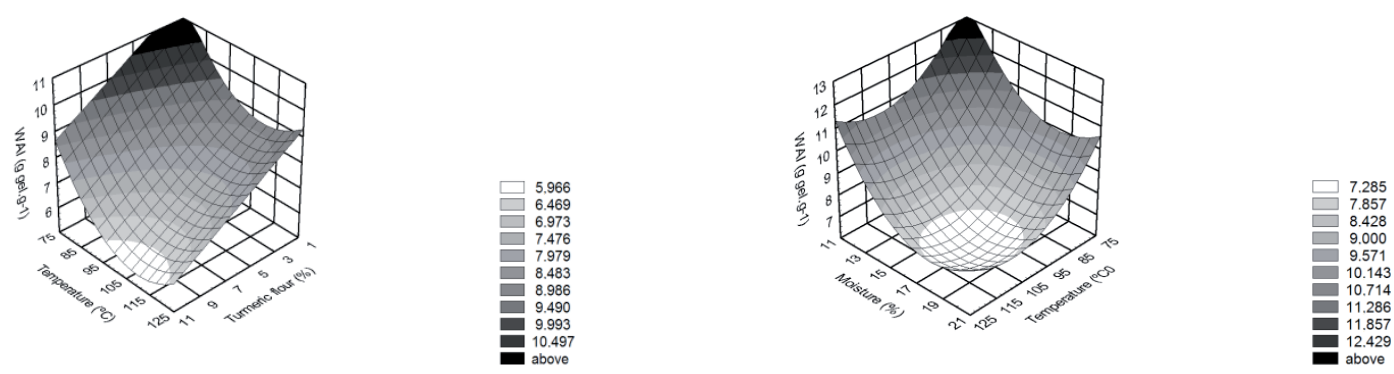

Figure 2 - Effect of temperature, moisture and amount of turmeric flour on water absorption index of extruded snacks.
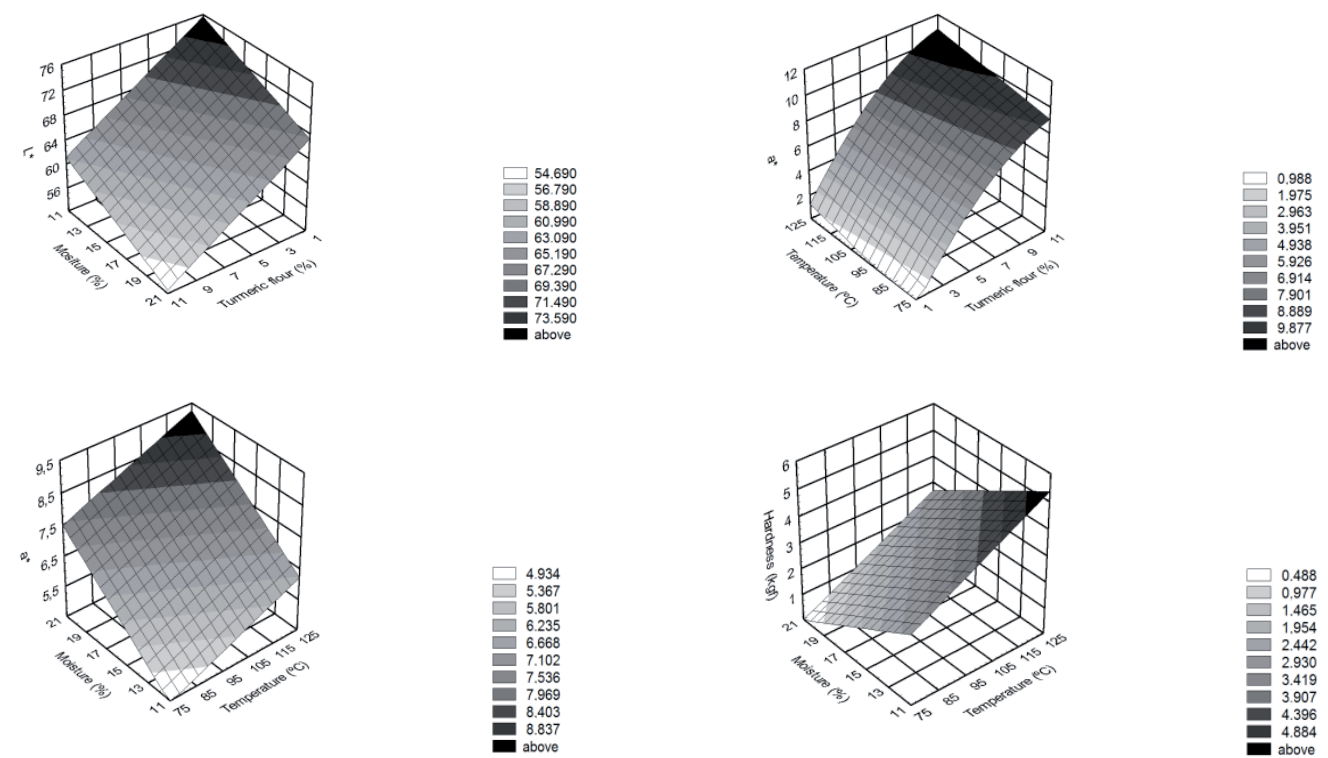

Figure 3 - Effect of temperature, moisture and amount of turmeric flour on luminosity (A), a* value (B and C), and hardness (D) of extruded snacks. 
an increase of this chromaticity component after extrusion. Regression analysis indicated effects of amount of turmeric flour, temperature and moisture on $b^{*}$ values (Table 2). The model was not significant and it cannot be used as a predictor model due the low coefficient of determination and significant lack of fit.

The hardness and crispness of expanded extrudate is a perception of the human being and is associated with the expansion and cell structure of the product. The hardness is the maximum force required for a probe to penetrate the extrudate. Results showed that hardness of extruded products ranged from 0.86 to $4.33 \mathrm{Kgf}$. Regression analysis showed pronounced effect of extrusion temperature and moisture on this parameter (Table 2). Conditions of high moisture and low extrusion temperature are observed lower hardness values (Figure 3).

With increasing water content, there is a reduction in the viscosity of the dough, the starch gelatinization is reduced and growth of bubbles is suppressed resulting in denser product. However increasing the extrusion temperature decreases the viscosity of the melt favors the growth of bubbles and produces snacks with low density and high crispness (Ding et al., 2005).

Results of sensorial analysis showed that snacks had good acceptance. The percentages of "liked" responses were: $35.5 \%$ "liked slightly" (assigned value 6), 26.3\% "liked regularly" (assigned value 7) and 21.0\% "like" (assigned value 8).

It is important to emphasize that the snacks were not coated with condiments normally used in commercial snacks production and this fact may have contributed to reduce their scores in the sensory analysis.

\section{CONCLUSIONS}

Physical characteristics of extruded snacks of cassava and turmeric are influenced by processing variables. In conditions of low moisture (12\%), low amount of turmeric flour (5\%), intermediate temperature in $3^{\text {th }}$ zone of extruder $\left(105^{\circ} \mathrm{C}\right)$ and screw speed $(250 \mathrm{rpm})$ it is possible making by single screw extrusion cassavaturmeric snacks with good global acceptance and technological characteristics similar to the commercial products. These results point out the importance to consider cassava and turmeric flours as potential raw materials to extrusion process for preparation of snacks.

\section{REFERENCES}

ANDERSON, R.A. et al. Gelatinization of corn grits by roll and extrusion cooking. Cereal Science Today, 14(1):4-12, 1969.
ANTON, A.A.; LUCIANO, F.B. Instrumental textural evaluation of extruded snack foods: A review. Ciência e Tecnologia de Alimentos, 5(4):245-251, 2007.

ANTON, A.A.; FULCHER, R.G.; ARNTFIELD, S.D. Physical and nutritional impact of fortification of corn starch-based extruded snacks with common bean (Phaseolus vulgaris L.) flour: effects of bean addition and extrusion cooking. Food Chemistry, 113(4):989-996, 2009.

ASSOCIATION OF OFFICIAL AGRICULTURAL CHEMISTS. A.O.A.C. Official methods of analysis. HORWITZ W. (ED.) $17^{\text {th }}$ ed. Gaithersburg, Maryland, 2000.

APRUZZESE, F. et al. In-line measurement of residence time distribution in a co-rotating twin-screw extruder. Food Research International, 36(5):461467, 2003.

\section{BRAZIL. Ministry of Agriculture, Livestock and} Supply. Normative instruction $\mathrm{n}^{\circ}$ 52. Official Gazette, Section 1, n.214, 2011.

DE PILLI, T. et al. Study of starch-lipid complexes in model system and real food produced using extrusingcooking technology. Innovative Food Science and Emerging Technologies, 12(4):610-616, 2011.

DING, Q.B. et al. The effect of extrusion conditions on the physicochemical properties and sensory characteristics of rice-based expanded snacks. Journal of Food Engineering, 66(3):283-289, 2005.

DOGAN, H.; KARWE, M.V. Physicochemical properties of quinoa extrudates. Food Science and Technology International, 9(2):101-114, 2003.

HAGENIMANA, A.; DING, X.; FANG, T. Evaluation of rice flour modified by extrusion cooking. Journal of Cereal Science, 43(1):38-46, 2006.

JYOTHI, A.N.; MOORTHY, S.N.; VIMALA, B. Physicochemical and functional properties of starch from two species of Curcuma. International Journal of Food Properties, 6(1):135-145, 2003.

KUMAR, G.S. et al. Free and bound phenolic antioxidants in amla (Emblica officinalis) and turmeric (Curcuma longa). Journal of Food Composition and Analysis, 19(5):446-452, 2006. 
LEONEL, M.; FREITAS, T.S.; MISCHAN, M.M. Physical characteristics of extruded cassava starch. Scientia Agricola, 66(4):486-493, 2009.

LUSTOSA, B.H.B. et al. Cassava instant flour: effect of extrusion conditions on thermal and viscosity properties. Acta Scientiarum Technology, 31(2):231-238, 2009.

MARZEC, A.; LEWICKI, P.P. Antiplasticization of cereal-based products by water. Part I: extruded flat bread. Journal of Food Engineering, 73(1): 1-8, 2006.

PANNEERSELVAM, R. et al. Carbohydrate metabolism in Dioscorea esculenta (Lour.) Burk. Tubers and Curcuma longa L. rhizomes during two phases of dormancy. Colloids and Surfaces B: Biointerfaces, 59(1):59-66, 2007.

SINGH, S.; GAMILATH, S.; WAKELING, L. Nutritional aspects of food extrusion: a review. International Journal of Food Science and Technology, 42(8):916-929, 2007.
SUPPAKUL, P. et al. Empirical modeling of moisture sorption characteristics and mechanical and barrier properties of cassava flour film and their relation to plasticizing-antiplasticizing effects. LWT Food Science and Technology, 50(1):290-297, 2013.

VALADEZ-BLANCO, R. et al. In-line colour monitoring during food extrusion: Sensitivity and correlation with product colour. Food Research International, 40(9):1129-1139, 2007.

YAGCI, S.; GOGUS, F. Response surface methodology for evaluation of physical and functional properties of extruded snack foods developed from food-byproducts. Journal of Food Engineering, 86(1):122$132,2008$.

YULIANI, S. et al. Effect of extrusion parameters on flavor retention, functional and physical properties of mixtures of starch and D-limonene encampsulated in milk protein. International Journal of Food Science, 41(2):83-94, 2006. 